\title{
A novel assay based on pre-equilibrium titration curves for the determination of enzyme inhibitor binding kinetics
}

\author{
Bernard Noppen ${ }^{1} \cdot$ Anouk Vanbelle $^{1,2} \cdot$ Alan W. Stitt $^{1,3} \cdot$ Marc Vanhove $^{1}(\mathbb{C}$ \\ Received: 18 February 2021 / Revised: 10 May 2021 / Accepted: 9 June 2021 / Published online: 22 June 2021 \\ (c) The Author(s) 2021
}

\begin{abstract}
Selection of pharmacological agents based on potency measurements performed at equilibrium fail to incorporate the kinetic aspects of the drug-target interaction. Here we describe a method for screening or characterization of enzyme inhibitors that allows the concomitant determination of the equilibrium inhibition constant in unison with rates of complex formation and dissociation. The assay is distinct from conventional enzymatic assays and is based on the analysis of inhibition curves recorded prior to full equilibration of the system. The methodology is illustrated using bicyclic peptide inhibitors of the serine protease plasma kallikrein.
\end{abstract}

Keywords Enzyme inhibition assay · Pre-equilibrium inhibition curves $\cdot$ Tight-binding inhibitors

\section{Introduction}

The intrinsic potency of a given drug is generally expressed on the basis of the affinity for its molecular target, and metrics such as $\mathrm{IC}_{50}$ 's, $\mathrm{K}_{\mathrm{D}}$ 's or $\mathrm{K}_{\mathrm{i}}$ 's are broadly used to select and prioritize lead compounds. However, such parameters reflect an affinity measured at equilibrium and thus fail to describe the kinetic aspects of the drug-target interaction and the time-dependent changes in target engagement.

Macroscopically, the kinetics of drug-target interaction can be represented by the rate of complex formation $\left(\mathrm{k}_{\text {on }}\right)$ and dissociation $\left(\mathrm{k}_{\mathrm{off}}\right)$. Similarly, the time a drug spends in contact with its biological target, referred to as residence time, reflects the inverse of the rate constant for drug-target unbinding (i.e., 1/ $\mathrm{k}_{\text {off }}$ ) (Bernetti et al. 2017; Pan et al. 2013; Tonge 2018).

Recently, the kinetic aspects of drug-target interaction have received ever-growing attention from the drug discovery community following the observation that therapeutic

Marc Vanhove

marc.vanhove@oxurion.com

Oxurion N.V, Gaston Geenslaan 1, 3001 Leuven, Belgium

2 Present Address: Ordina Belgium, Blarenberglaan 3B, 2800 Mechelen, Belgium

3 Centre for Experimental Medicine, Queen's University Belfast, Northern Ireland, United Kingdom efficacy can be significantly influenced by the kinetics of drug-target interaction and residence time (Bernetti et al. 2017, 2019; Pan et al. 2013; Tonge 2018; Di Trani et al. 2018; Shimizu et al. 2016; Zeilinger et al. 2017). Analytical methods aiming to provide accurate determination of the rate of drug-target complex formation and dissociation are thus expected to become part of the routine arsenal of tools for drug candidate screening and characterization.

Among potential molecular targets, enzymes, and in particular proteases, are regarded as highly attractive, the latter representing an estimated 5 to $10 \%$ of all pharmaceutical targets (Drag 2010). Here we report a method to study the interaction of enzyme inhibitors with their cognate target based on the analysis of pre-equilibrium inhibition curves. The method is distinct from conventional enzymatic assays, is applicable to highly potent molecules, and allows the determination of the kinetic parameters $\mathrm{k}_{\text {on }}$ and $\mathrm{k}_{\text {off }}$, together with the equilibrium inhibition constant $\mathrm{K}_{\mathrm{i}}$, from a single experiment.

\section{Method}

The potency of reversible enzyme inhibitors is best described by the equilibrium inhibition constant $\mathrm{K}_{\mathrm{i}}$. Poorly potent molecules can easily be studied experimentally under conditions where the total enzyme concentration $\mathrm{E}_{0}$ in the assay is smaller than the inhibition constant $\mathrm{K}_{\mathrm{i}}\left(\mathrm{E}_{0}<<\mathrm{K}_{\mathrm{i}}\right)$ and where 
the total concentration of inhibitor $I_{0}$ used in the assay is larger than the total enzyme concentration $\left(\mathrm{I}_{0}>>\mathrm{E}_{0}\right)$. Under these conditions, mathematically simplified binding models, obtained by assuming that the concentration of inhibitor at equilibrium $\mathrm{I}_{\mathrm{e}}$ is equal to the total concentration of inhibitor $\left(\mathrm{I}_{\mathrm{e}}=\mathrm{I}_{0}\right)$, can be used for data analysis and $\mathrm{K}_{\mathrm{i}}$ determination. However, the development of highly potent molecules by the pharmaceutical industry often forces the experimental determination of $\mathrm{K}_{\mathrm{i}}$ to be conducted under conditions where $\mathrm{E}_{0} \sim \mathrm{K}_{\mathrm{i}}$ or $\mathrm{E}_{0}>\mathrm{K}_{\mathrm{i}}$, and where $\mathrm{I}_{0} \sim \mathrm{E}_{0}$. Under these conditions, analysis of experimental data, typically in the form of plots representing the residual enzymatic activity measured at equilibrium as a function of the inhibitor concentration (Fig. 1A), requires the use of non-simplified mathematical models derived from the theory of tight binding inhibitors, such as Eq. 1, were $\mathrm{v}_{\mathrm{i}}$ and $\mathrm{v}_{\mathrm{o}}$ represent the rate of substrate hydrolysis in the presence and absence of the inhibitor, $\mathrm{E}_{0}$ and $\mathrm{I}_{0}$ the total concentration of enzyme and inhibitor, and $\mathrm{K}_{\mathrm{i} \text {,app }}$ the apparent inhibition constant (Lindhout et al. 1994; Teufel et al. 2018; Ulmer et al. 1995; Yiallouros et al. 1998). Incidentally, the way $\mathrm{K}_{\mathrm{i} \text {,app }}$ is linked to the real inhibition constant depends on the inhibition mechanism; e.g., for competitive inhibition, $\mathrm{K}_{\mathrm{i} \text {,app }}$ can be expressed as in Eq. 2, where [S] and $\mathrm{K}_{\mathrm{m}}$ are the substrate concentration and the Michaelis-Menten constant of the enzyme for this particular substrate, respectively (Teufel et al. 2018; Masuda-Momma et al. 1993; Wilkes and Prescott 1985): i.e., the concentration of enzyme-inhibitor complex at any time $\mathrm{t}$, as a function of $\mathrm{k}_{\text {on }}, \mathrm{k}_{\text {off }}, \mathrm{E}_{0}$ and $\mathrm{I}_{0}$ (Eq. 5):

$$
\begin{aligned}
& \int_{0}^{\mathrm{t}} \frac{\mathrm{d}[\mathrm{EI}]_{\mathrm{t}}}{\mathrm{k}_{\mathrm{on}} \cdot\left(\mathrm{E}_{0}-[\mathrm{EI}]_{\mathrm{t}}\right) \cdot\left(\mathrm{I}_{0}-[\mathrm{EI}]_{\mathrm{t}}\right)-\mathrm{k}_{\mathrm{off}} \cdot[\mathrm{EI}]_{\mathrm{t}}}=\int_{0}^{\mathrm{t}} \mathrm{dt} \\
& {[\mathrm{EI}]_{\mathrm{t}}=\frac{\mathrm{a} \cdot(1-\mathrm{c})-\mathrm{b} \cdot(1+\mathrm{c})}{2 \cdot \mathrm{k}_{\mathrm{on}} \cdot(1-\mathrm{c})}}
\end{aligned}
$$

with

$\mathrm{a}=\mathrm{k}_{\mathrm{on}} \cdot\left(\mathrm{E}_{0}+\mathrm{I}_{0}\right)+\mathrm{k}_{\text {off }}$

$\mathrm{b}=\sqrt{\mathrm{a}^{2}-4 \cdot \mathrm{k}_{\mathrm{on}}^{2} \cdot \mathrm{E}_{0} \cdot \mathrm{I}_{0}}$

$c=\left(\frac{a-b}{a+b}\right) \cdot e^{-b \cdot t}$

since

$\mathrm{v}_{\mathrm{i}}=\mathrm{v}_{0} \cdot \frac{\mathrm{E}_{0}-[\mathrm{EI}]_{\mathrm{t}}}{\mathrm{E}_{0}}$

combining Eq. (5) and (6) leads to Eq. 7, which can be used to analyze data representing the residual enzymatic activity measured as a function of the inhibitor concentra-

$\mathrm{v}_{\mathrm{i}}=\mathrm{v}_{\mathrm{o}} \times \frac{1}{\mathrm{E}_{0}} \times\left(\mathrm{E}_{0}-\frac{\left(\mathrm{E}_{0}+\mathrm{I}_{0}+\mathrm{K}_{\mathrm{i}, \text { app }}\right)-\sqrt{\left(\mathrm{E}_{0}+\mathrm{I}_{0}+\mathrm{K}_{\mathrm{i}, \text { app }}\right)^{2}-4 \times \mathrm{E}_{0} \times \mathrm{I}_{0}}}{2}\right)$

$\mathrm{K}_{\mathrm{i}, \mathrm{app}}=\mathrm{K}_{\mathrm{i}} \cdot\left(1+\frac{[\mathrm{S}]}{\mathrm{K}_{\mathrm{m}}}\right)$

Recently, Vanhove and Vanhove (2018) described mathematical equations which, adapted to the problem posed here, can be used to model the time-dependence of enzyme-inhibitor complex formation. The model is derived from the differential equation describing a 1:1 interaction between the enzyme $E$ and the inhibitor I according to I+E $\leftrightarrow$ IE (Eq. 3, with $\mathrm{k}_{\text {on }}$ and $\mathrm{k}_{\text {off }}$ the second order rate constant for complex formation and the first-order rate constant for complex dissociation, respectively):

$\frac{\mathrm{d}[\mathrm{EI}]_{\mathrm{t}}}{\mathrm{dt}}=\mathrm{k}_{\mathrm{on}} \cdot\left(\mathrm{E}_{0}-[\mathrm{EI}]_{\mathrm{t}}\right) \cdot\left(\mathrm{I}_{0}-[\mathrm{EI}]_{\mathrm{t}}\right)-\mathrm{k}_{\text {off }} \cdot[\mathrm{EI}]_{\mathrm{t}}$.

Vanhove and Vanhove provided an analytical solution to Eq. 4 which leads to the integrated equation expressing $[\mathrm{EI}]_{\mathrm{t}}$, tion under pre-equilibrium conditions (Fig. 1B):

$\mathrm{v}_{\mathrm{i}}=\mathrm{v}_{0} \cdot \frac{1}{\mathrm{E}_{0}} \cdot\left(\mathrm{E}_{0}-\frac{\mathrm{a} \cdot(1-\mathrm{c})-\mathrm{b} \cdot(1+\mathrm{c})}{2 \cdot \mathrm{k}_{\mathrm{on}} \cdot(1-\mathrm{c})}\right)$.

Worth mentioning, Eq. 7 is obtained without any mathematical simplification and can thus be used to study highly potent molecules requiring experimental conditions where $\mathrm{I}_{0} \sim \mathrm{E}_{0}$ (see discussion above). Another aspect of the method described here is that it does not require full equilibration of the system and it is, therefore, well suited for slowly equilibrating reactions, unlike conventional $\mathrm{K}_{\mathrm{i}}$ measurements, where the time needed to reach the equilibrium may exceed the time during which the studied biomolecules are stable (Vanhove and Vanhove 2018).

We chose to characterize bicyclic peptide inhibitors of the serine protease plasma kallikrein (PKal) to evaluate the methodology described here in practice. Bicyclic peptides are constrained peptides consisting of a peptide sequence containing 3 cysteine residues which are covalently linked 

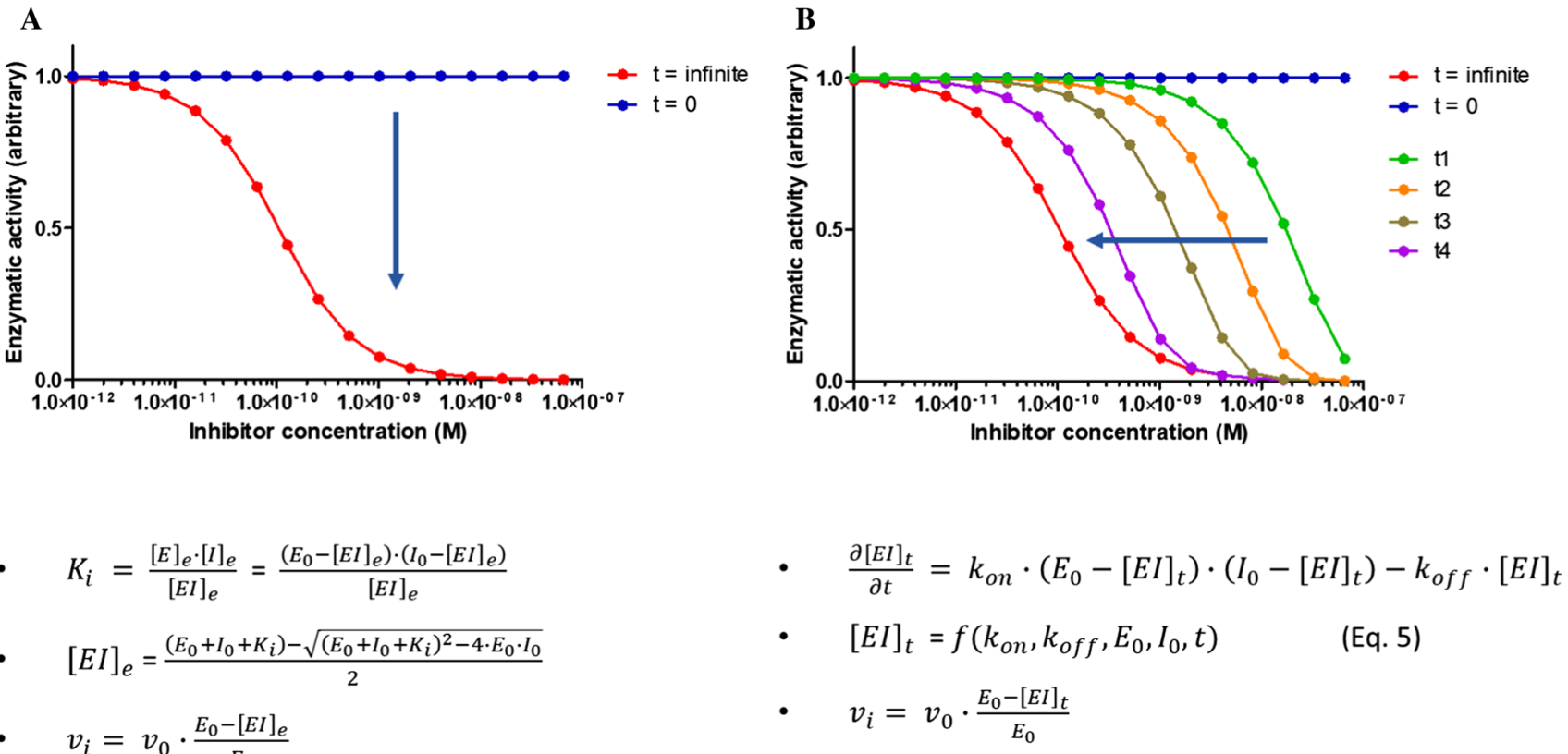

Fig. 1 Illustration of equilibrium vs pre-equilibrium studies. A Data obtained at equilibrium are plotted as measured signal (e.g., enzymatic activity) vs. inhibitor concentration and analyzed using a model derived from the expression of the equilibrium constant. B Data obtained prior to equilibrium are plotted as measured signal vs. inhib-

itor concentration for different amounts of time and analyzed using a model derived from the differential equation describing the change in enzyme-inhibitor complex concentration over time. The dots in $\mathbf{A}$ and $\mathbf{B}$ are there for illustration purposes and were generated by mathematical simulation

to a thiol-reactive molecular scaffold (Fig. 2) (Heinis et al. 2009; Rhodes and Dehua 2017). Bicyclic peptides are conformationally more constrained than their linear counterpart, and their preorganized, rigid structures confer high affinity binding, high specificity and superior stability (Chen

et al. 2012). Furthermore, the use of structurally diverse cyclization reagents, such as 1,3,5-tris(bromomethyl)benzene (TBMB), 1,3,5-triacryoyl-1,3,5-triazinane (TATA), $\mathrm{N}, \mathrm{N}^{\prime}, \mathrm{N}^{\prime \prime}$-(benzene-1,3,5-triyl)-tris(2-bromoacetamide) (TBAB) or $\mathrm{N}, \mathrm{N}^{\prime}, \mathrm{N}^{\prime \prime}$-benzene-1,3,5-triyltrisprop-2-enamide

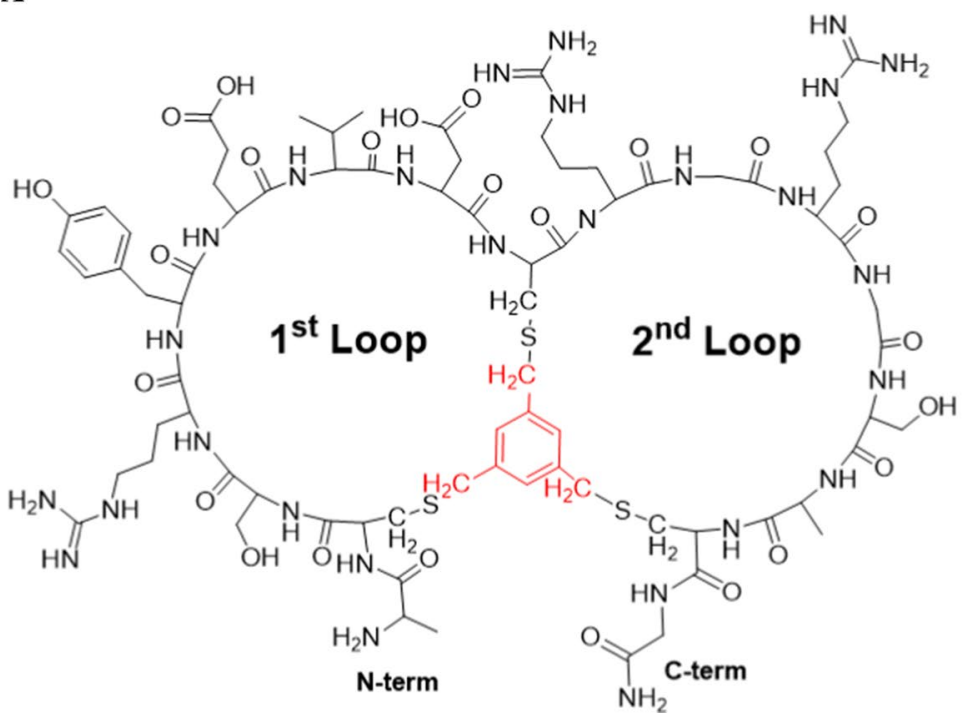

B

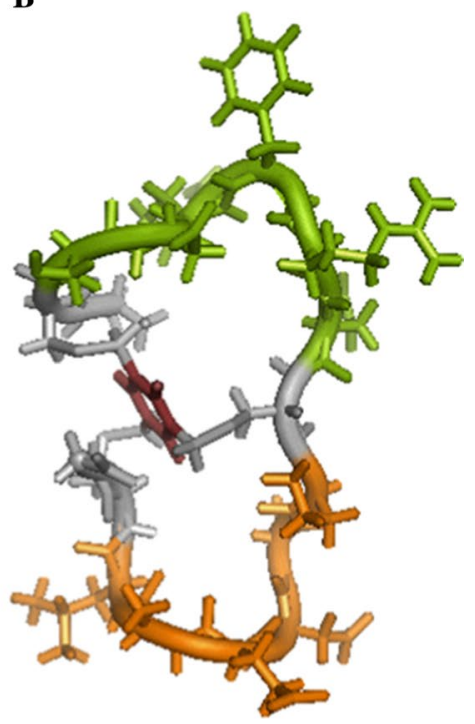

Fig. 2 Representative structure $\mathbf{A}$ and 3D-fold $\mathbf{B}$ of 1,3,5-tris(bromomethyl)benzene (TBMB)-based bicyclic peptides. The structure shown in red (A) and dark brown (B) is the residual TBMB moiety following cyclization 
Table 1 Plasma kallikrein bicyclic peptide inhibitors and their corresponding sequences

\begin{tabular}{|c|c|}
\hline Peptide & Sequence, cyclized on $\mathrm{C}_{\mathrm{i}}, \mathrm{C}_{\mathrm{ii}}, \mathrm{C}_{\mathrm{iii}}$ by TBMB \\
\hline $1 b$ & Ac- $\mathrm{C}_{\mathrm{i}} \mathrm{NTWNPWC} \mathrm{Cii}_{\mathrm{ii}} \mathrm{PWDAPLC}_{\mathrm{iii}} \mathrm{A}-\mathrm{Sar}_{3}-[\mathrm{D}-\mathrm{Arg}]_{2}$ \\
\hline $2 b$ & Ac- $\mathrm{C}_{\mathrm{i}}$ SWPARC $_{\mathrm{ii}} \mathrm{LHQDLC}_{\mathrm{iii}}$ \\
\hline $2 \mathrm{c}$ & Ac-C SFPYRC $_{\mathrm{ii}}$ LHQDLC $_{\mathrm{iii}}$ \\
\hline $2 \mathrm{~d}$ & Ac- $\mathrm{C}_{\mathrm{i}} \mathrm{SF}[\mathrm{Aze}] \mathrm{Y}[\mathrm{HArg}] \mathrm{C}_{\mathrm{ii}}\left[\mathrm{Ala}\left(\psi \mathrm{CH}_{2}-\mathrm{NH}\right)\right] \mathrm{HQDLC} \mathrm{C}_{\mathrm{iii}}$ \\
\hline $4 b$ & Ac- $C_{\mathrm{i}} \mathrm{SF}[\mathrm{Aze}] \mathrm{Y}[\mathrm{HArg}] \mathrm{C}_{\mathrm{ii}} \mathrm{VYYPDIC}_{\mathrm{iii}} \mathrm{A}-\mathrm{Sar}_{3}-[\mathrm{D}-\mathrm{Arg}]_{2}$ \\
\hline $5 \mathrm{a}$ & Ac-C $\mathrm{S}_{\mathrm{i}} \mathrm{SPYRC}_{\mathrm{ii}}$ LHQDLC $_{\mathrm{iii}}$ \\
\hline $5 b$ & Ac-C ${ }_{\mathrm{i}}$ SFPY[HArg] $\mathrm{C}_{\mathrm{ii}}$ LHQDLC $_{\mathrm{iii}}$ \\
\hline $5 \mathrm{c}$ & Ac- $C_{\mathrm{i}} \mathrm{SF}[\mathrm{Aze}] \mathrm{Y}[\mathrm{HArg}] \mathrm{C}_{\mathrm{ii}}$ LHQDLC $_{\mathrm{iii}}$ \\
\hline $5 d$ & Ac- $C_{\mathrm{i}} \mathrm{SF}[\mathrm{Aze}] \mathrm{Y}[\mathrm{NMeArg}] \mathrm{C}_{\mathrm{ii}} \mathrm{LHQDLC}_{\mathrm{iii}}$ \\
\hline
\end{tabular}

Peptides 1b, 2b, 2c, 2d and 4b were previously described (Teufel et al., 2018). Standard one letter code was used for natural amino acids. D-Arg: D enantiomer of arginine. Non-natural amino acids: Aze: azetidine-carboxylic acid, HArg: homoarginine, Sar: sarcosine, NMeArg: N-methylarginine. The first, second and third cysteine residues, which are cyclized by thioether formation with 1,3,5-tris(bromomethyl)benzene (TBMB), are designated as $\mathrm{C}_{\mathrm{i}}, \mathrm{C}_{\mathrm{i}}$, $\mathrm{C}_{\mathrm{iii}}$, respectively. All peptides are amidated C-terminally and contain an N-terminus capped by an acetyl group (referred to as "Ac")

(TAAB) that are able to impose different backbone conformations enables the identification of molecules which cover a wide range of chemical space (Chen et al. 2012).

The TBMB-based bicyclic peptide inhibitors of PKal used in this study are listed in Table 1, some of which have been described previously (Teufel et al. 2018). Experiments were performed at $25^{\circ} \mathrm{C}$ in $20 \mathrm{mM}$ Tris- $\mathrm{HCl}$, $150 \mathrm{mM} \mathrm{NaCl}, 1 \mathrm{mM}$ EDTA, 0.1\% PEG-6000, 0.1\% Triton $\mathrm{X}-100$, pH 7.5. Human PKal (Molecular Innovations, cat. HPKA, typical nominal concentration $1 \mathrm{nM}$ for all peptides except $0.25 \mathrm{nM}$ for peptide $4 \mathrm{~b}$ ) was pre-incubated in 96-well plates with different concentrations of the tested peptide (typically a serial twofold dilution plus a control with no peptide) in a reaction volume of $90 \mu \mathrm{L}$. At different timepoints, the fluorogenic substrate H-Pro-Phe-ArgAMC (Bachem, cat. I-1295.0050, $10 \mu \mathrm{L}, 20 \mu \mathrm{M}$ final) was added to the relevant wells, and the increase in fluorescence at $480 \mathrm{~nm}$ (with excitation at $360 \mathrm{~nm}$ ) was recorded using a Spectramax M2e plate reader (Molecular Devices). Initial rates of substrate hydrolysis were obtained by linear fit of the raw fluorescence vs. time traces. In addition, fluorescence was recorded ensuring that no more than $10 \%$ of the substrate were hydrolyzed, and for periods of time (typically 30-60 s) short enough to obtain linear traces. The data were plotted as the initial rate of substrate hydrolysis vs. peptide concentration for the different times of incubation prior to substrate addition (as shown in Fig. 3) and analyzed using Eq. 7.

To compute unique values of $\mathrm{k}_{\text {on }}$ and $\mathrm{k}_{\text {off }}$, data sets such as those of Fig. 3 must be analyzed "globally", i.e., considering all pre-equilibrium inhibition curves as a unique data set, as allowed by modern nonlinear regression analysis software's. In this study, we used GraphPad Prism ver. 5.02 (GraphPad Software Inc., La Jolla, CA) applying equal weighting (i.e., performing minimization based on absolute distances squared), and we invite the reader to consult the software's user's manual for a detailed description of how global fitting of such data sets can be performed (https://cdn. graphpad.com/faq/2/file/Prism_v5_Regression_Guide.pdf). One point to highlight is that the parameters $\mathrm{k}_{\mathrm{on}}, \mathrm{k}_{\mathrm{off}}$ and $\mathrm{E}_{0}$ should be "shared", to employ the terminology used in GraphPad Prism, i.e., that one unique value of these parameters is used to fit the data. By contrast, as far as the term $\mathrm{v}_{0}$ is concerned, we found that it can be either shared or allowed to take distinct values for the inhibition curves obtained at different timepoints to accommodate for a certain degree

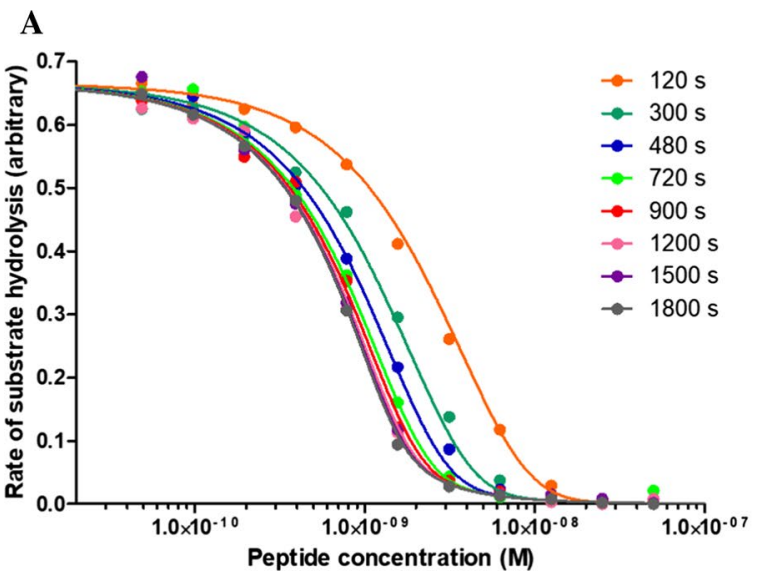

Fig. 3 Inhibition of human plasma kallikrein by peptide $5 \mathrm{c}(\mathbf{A})$ and $1 \mathrm{~b}$ (B) under pre-equilibrium conditions. Each dot corresponds to a single measurement of initial rate of substrate hydrolysis. The solid

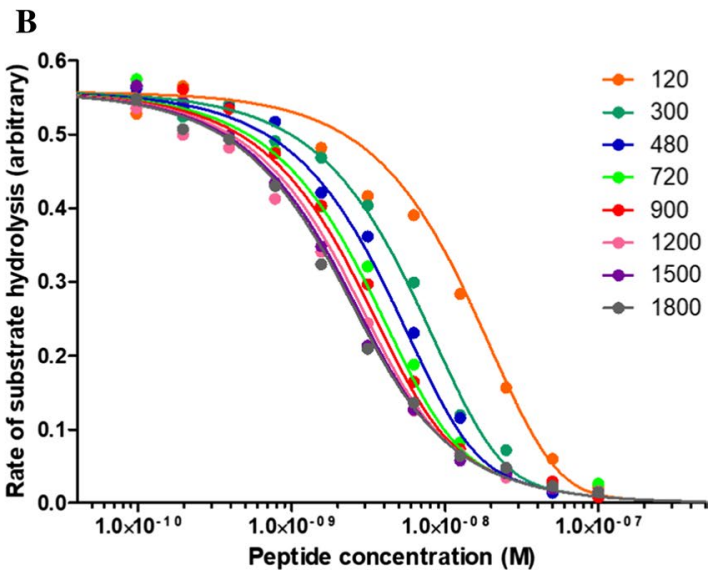

lines represent the best fit using Eq. $7 . \mathrm{K}_{\mathrm{i}}, \mathrm{k}_{\text {on }}$ and $\mathrm{k}_{\text {off }}$ values obtained from these data are reported in Table 2 
of experimental variability in initial rate measurements. As discussed previously for the analysis of data obtained under equilibrium, i.e., using Eq. 1 (see Teufel et al. 2018), the term $\mathrm{E}_{0}$ in Eq. 7 can be treated as a shared but adjustable parameter or, as here, fixed to its known value. The terms $\mathrm{v}_{0}, \mathrm{k}_{\mathrm{on}}$ and $\mathrm{k}_{\text {off }}$, by contrast, always need to be treated as adjustable parameters. Finally, the knowledge of the kinetic parameters $\mathrm{k}_{\mathrm{on}}$ and $\mathrm{k}_{\mathrm{off}}$ enables calculation of the equilibrium inhibition constant $\mathrm{K}_{\mathrm{i}}\left(\mathrm{K}_{\mathrm{i}}=\mathrm{k}_{\text {off }} / \mathrm{k}_{\text {on }}\right)$.

Strictly speaking, and similarly to measurements performed at equilibrium, all three parameters considered here, namely $\mathrm{k}_{\mathrm{on}}, \mathrm{k}_{\text {off }}$ and $\mathrm{K}_{\mathrm{i}}$, should be regarded as "apparent" (app) parameters, with their relationship to the actual parameters depending on the inhibition mechanism, e.g., for competitive inhibition, Eqs. 8-10 apply (Lindhout et al. 1994; Masuda-Momma et al. 1993; Yiallouros et al. 1998; Bakker et al. 1990):

$\mathrm{K}_{\mathrm{i}, \mathrm{app}}=\frac{\mathrm{k}_{\text {off,app }}}{\mathrm{k}_{\text {on,app }}}$

$\mathrm{k}_{\mathrm{on}, \mathrm{app}}=\frac{\mathrm{k}_{\mathrm{on}}}{1+\frac{[\mathrm{S}]}{\mathrm{K}_{\mathrm{m}}}}$

$\mathrm{k}_{\text {off,app }}=\mathrm{k}_{\text {off }}$

In the case of H-Pro-Phe-Arg-AMC, however, the $\mathrm{K}_{\mathrm{m}}$ for human PKal is large (Teufel et al. 2018) and experiments were performed under conditions where $[\mathrm{S}]<<\mathrm{K}_{\mathrm{m}}$. Therefore, the values for $\mathrm{k}_{\mathrm{on}}, \mathrm{k}_{\text {off }}$ and $\mathrm{K}_{\mathrm{i}}$ reported here can be considered as representing actual values.

\section{Results and discussion}

Nine bicyclic peptides (Table 1) were tested for their ability to inhibit human PKal using the procedure described above. Representative data sets are shown in Fig. 3 for peptides 5c and $1 \mathrm{~b}$ which are representative of higher and lower potency (lower and higher $\mathrm{K}_{\mathrm{i}}$ ), respectively. Data fitting with Eq. 7 allowed the determination of the kinetic parameters $\mathrm{k}_{\mathrm{on}}$ and $\mathrm{k}_{\text {off }}$ and, concomitantly, of the equilibrium inhibition constant $\mathrm{K}_{\mathrm{i}}$ from a single experiment and a single set of data. The $\mathrm{k}_{\mathrm{on}}, \mathrm{k}_{\text {off }}$ and $\mathrm{K}_{\mathrm{i}}$ values for the tested peptides are reported in Table 2 and graphically in Fig. 4. The robustness of the method is demonstrated by the consistently low variability (average CV within 15-20\%) of all measured parameters, whether $\mathrm{k}_{\mathrm{on}}, \mathrm{k}_{\text {off }}$ or $\mathrm{K}_{\mathrm{i}}$, obtained from independent measurements.

The $K_{i}$ values reported here for peptides $1 b, 2 b, 2 c, 2 d$ and $4 \mathrm{~b}$ are also in good agreement with those reported previously (Table 2; Teufel et al. 2018). $\mathrm{K}_{\mathrm{i}}$ values reported by Teufel et al (2018) were obtained from conventional equilibrium measurements, i.e., by analyzing inhibition titration curves supposedly recorded at equilibrium using Eq. 1 . Numerical simulations performed with Eq. 7 for, e.g., peptide $2 \mathrm{~d}$, however, show that an incubation time of $15 \mathrm{~min}$ as described by Teufel et al (2018), and under the conditions used by the authors (e.g., an enzyme concentration in the assay of $2 \mathrm{nM}$ ), is slightly less than the time needed to reach full equilibrium, and that this apparently very small deviation is sufficient to explain the difference in the Ki of peptide $2 \mathrm{~d}$ reported in this study $(0.22 \pm 0.04 \mathrm{nM})$ compared to the one reported previously $(0.36 \pm 0.07 \mathrm{nM})($ Fig. 5). A similar observation was made, e.g., for peptide $1 \mathrm{~b}$. This illustrates the advantage of the methodology proposed here, which eliminates the need to achieve complete equilibration of the studied system.

All tested peptides proved to be potent inhibitors of human PKal, with $\mathrm{K}_{\mathrm{i}}$ values covering almost two orders of magnitude, ranging from single-digit nanomolar to doubledigit picomolar values. Progression towards higher affinity (i.e., lower $\mathrm{K}_{\mathrm{i}}$ values) resulted from both an increase in the rate of complex formation and a reduction in the rate of complex dissociation, both $\mathrm{k}_{\text {on }}$ and $\mathrm{k}_{\text {off }}$ evolving by $\sim 1.0-1.5$ order of magnitude. This is illustrated graphically by the
Table 2 Kinetic parameters $\mathrm{k}_{\mathrm{on}}$ and $\mathrm{k}_{\text {off }}$ and equilibrium inhibition constant $\mathrm{K}_{\mathrm{i}}$ for plasma kallikrein bicyclic peptide inhibitors. Values are reported as mean \pm standard deviation of at least 3 independent measurements

\begin{tabular}{|c|c|c|c|c|}
\hline Peptide & $\begin{array}{l}\mathrm{k}_{\mathrm{on}} \\
\left(\mathrm{M}^{-1} \mathrm{~s}^{-1}\right)\end{array}$ & $\begin{array}{l}\mathrm{k}_{\text {off }} \\
\left(\mathrm{s}^{-1}\right)\end{array}$ & $\begin{array}{l}\mathrm{K}_{\mathrm{i}} \\
(\mathrm{nM})\end{array}$ & $\begin{array}{l}\mathrm{K}_{\mathrm{i}}(\mathrm{nM}) \\
\text { from Teufel et al. } 2018\end{array}$ \\
\hline $1 b$ & $(3.86 \pm 0.58) 10^{5}$ & $(7.0 \pm 1.3) 10^{-4}$ & $1.8 \pm 0.2$ & $3.0 \pm 0.3$ \\
\hline $2 b$ & $(5.7 \pm 1.1) 10^{6}$ & $(5.82 \pm 0.49) 10^{-4}$ & $0.10 \pm 0.02$ & $0.15 \pm 0.18$ \\
\hline $2 \mathrm{c}$ & $(2.40 \pm 0.18) 10^{6}$ & $(8.2 \pm 1.7) 10^{-4}$ & $0.34 \pm 0.04$ & $0.39 \pm 0.17$ \\
\hline $2 d$ & $(1.37 \pm 0.20) 10^{6}$ & $(2.99 \pm 0.52) 10^{-4}$ & $0.22 \pm 0.04$ & $0.36 \pm 0.07$ \\
\hline $4 b$ & $(1.06 \pm 0.14) 10^{7}$ & $(1.49 \pm 0.41) 10^{-3}$ & $0.14 \pm 0.02$ & $0.25 \pm 0.20$ \\
\hline $5 \mathrm{a}$ & $(2.28 \pm 0.47) 10^{6}$ & $(7.88 \pm 0.40) 10^{-4}$ & $0.36 \pm 0.06$ & - \\
\hline $5 b$ & $(2.62 \pm 0.50) 10^{6}$ & $(1.38 \pm 0.13) 10^{-3}$ & $0.53 \pm 0.07$ & - \\
\hline $5 \mathrm{c}$ & $(3.5 \pm 1.2) 10^{6}$ & $(1.92 \pm 0.37) 10^{-4}$ & $0.061 \pm 0.027$ & - \\
\hline $5 d$ & $(8.0 \pm 1.3) 10^{5}$ & $(4.39 \pm 0.82) 10^{-4}$ & $0.55 \pm 0.06$ & - \\
\hline
\end{tabular}


Fig. $4 \mathrm{k}_{\text {on }}$ vs. $\mathrm{k}_{\text {off }}$ plot for the inhibition of human plasma kallikrein by the indicated bicyclic peptides. Error bars represent standard deviations as from Table 2. Individual peptide potency (expressed as $\mathrm{K}_{\mathrm{i}}$ ) is reported in the legend. The blue, dotted, diagonal lines graphically represent fixed $\mathrm{K}_{\mathrm{i}}$ values defined from constant $\mathrm{k}_{\text {off }}$ vs. $\mathrm{k}_{\text {on }}$ ratios

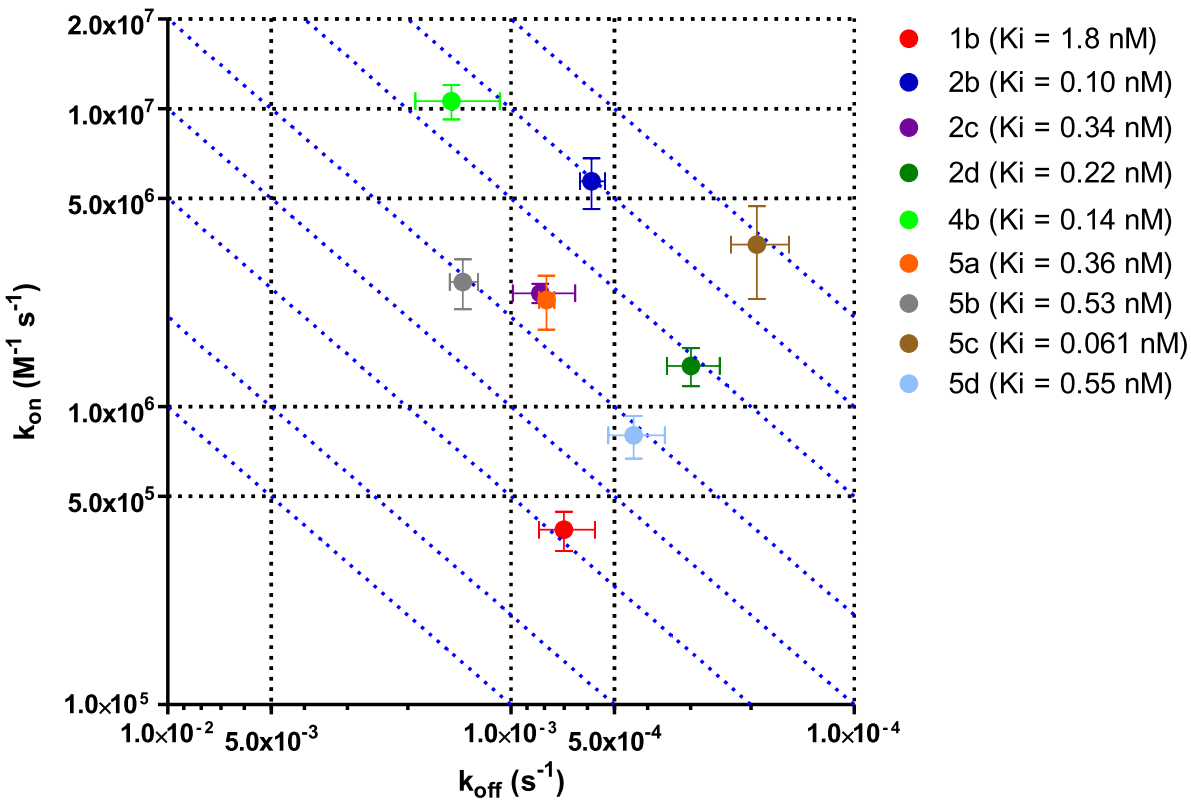

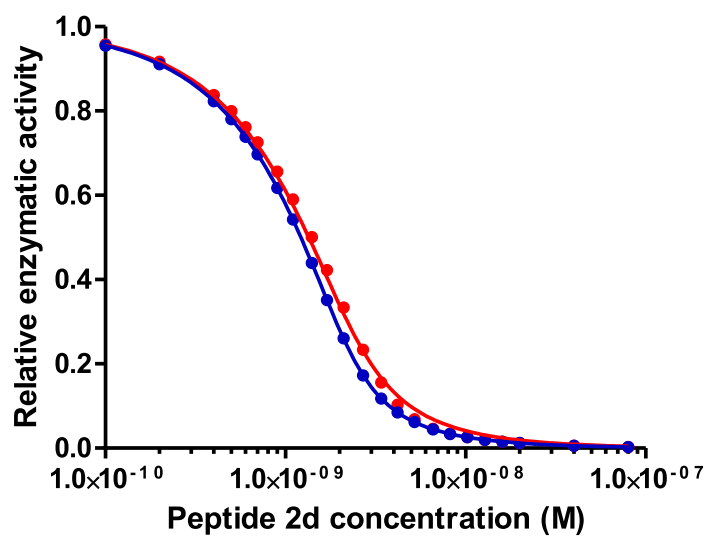

Fig. 5 Red dots: inhibition titration curve for peptide $2 \mathrm{~d}$ simulated using Eq. 7, assuming an enzyme concentration of $2 \mathrm{nM}, \mathrm{k}_{\text {on }}$ and $\mathrm{k}_{\text {off }}$ values as reported in Table 2, and an incubation time of $15 \mathrm{~min}$. Blue dots: inhibition titration curve for peptide $2 \mathrm{~d}$ at equilibrium, as predicted by either Eq. 1 or by Eq. 7 with $t=\infty$. Each set of data was separately analyzed with Eq. 1 (solid lines), leading to $\mathrm{K}_{\mathrm{i}}$ values of $0.35 \mathrm{nM}(\mathrm{t}=15 \mathrm{~min})$ and $0.22 \mathrm{nM}(\mathrm{t}=\infty)$

fact that peptides with increasing affinities move towards the upper right corner of the $\mathrm{k}_{\text {on }}$ vs. $\mathrm{k}_{\text {off }}$ plot of Fig. 4.

Sagawa et al (2003) have reported that antibodies progressing along the affinity maturation pathway by somatic hypermutations exhibit an increase in affinity that is the result of a decrease in both the on-rate and the off-rate (with, however, a larger amplitude for the latter). This pattern is interpreted assuming that higher affinity antibodies have acquired a more rigid structure allowing the antibody-antigen interaction to shift from a "zipper" to a "lock-and-key" mechanism, with as a result a reduced entropic cost for complex formation. One can speculate, however, that because of their constraint structure, affinity improvement of bicyclic peptides such as achieved from repeated selection rounds of peptide-on-phage libraries is primarily enthalpy-driven.

Finally, it is worth noting that the value of $\mathrm{k}_{\text {on }}$ and $\mathrm{k}_{\text {off }}$ reported here for PKal bicyclic peptide inhibitors are in the same range as those typically observed for antibodies (see e.g., Steukers et al. 2006). This suggests that the interaction of bicyclic peptides with their enzyme targets closely resembles conventional protein-protein interactions which are influenced by contact surface area with the enzyme target and a diverse range of non-covalent interactions.

\section{Conclusion}

With the recognition that the kinetics of drug-target interaction can influence therapeutic efficacy, the pharmaceutical industry is in need of robust assays which enable early and rapid screening of hits on the basis of both equilibrium and kinetic metrics. We propose a new methodology for the concomitant determination of the equilibrium inhibition constant $\mathrm{K}_{\mathrm{i}}$ and of the association and dissociation rate constants $\mathrm{k}_{\text {on }}$ and $\mathrm{k}_{\text {off }}$ of enzyme inhibitors based on the analysis of inhibition curves recorded at different timepoints prior to equilibration of the system. The model used here is obtained without mathematical simplification and can thus be applied to highly potent (also referred to as tight binding) inhibitors. Another aspect of the method is that it does not require full equilibration of the system, making it particularly well suited for the investigation of slowly equilibrating systems and timeframes which may exceed the time during which the studied molecules are stable. 
Open Access This article is licensed under a Creative Commons Attribution 4.0 International License, which permits use, sharing, adaptation, distribution and reproduction in any medium or format, as long as you give appropriate credit to the original author(s) and the source, provide a link to the Creative Commons licence, and indicate if changes were made. The images or other third party material in this article are included in the article's Creative Commons licence, unless indicated otherwise in a credit line to the material. If material is not included in the article's Creative Commons licence and your intended use is not permitted by statutory regulation or exceeds the permitted use, you will need to obtain permission directly from the copyright holder. To view a copy of this licence, visit http://creativecommons.org/licenses/by/4.0/.

\section{References}

Bakker AV, Jung S, Spencer RW, Vinick FJ, Faraci WS (1990) Slow tight-binding inhibition of prolyl endopeptidase by benzyloxycarbonyl-prolyl-prolinal. Biochem J 271:559-562

Bernetti M, Cavalli A, Mollica L (2017) Protein-ligand (un)binding kinetics as a new paradigm for drug discovery at the crossroad between experiments and modelling. MedChemComm 8:534-550

Bernetti M, Masetti M, Rocchia W, Cavalli A (2019) Kinetics of drug binding and residence time. Annu Rev Phys Chem 70:143-171

Chen S, Morales-Sanfrutos J, Angelini A, Cutting B, Heinis C (2012) Structurally diverse cyclisation linkers impose different backbone conformations in bicyclic peptides. ChemBioChem 13:1032-1038

Di Trani JM, De Cesco S, O’Leary R, Plescia J, do Nascimento CJ, Moitessier N, Mittermaier AK (2018) Rapid measurement of inhibitor binding kinetics by isothermal titration calorimetry. Commun Nat. https://doi.org/10.1038/s41467-018-03263-3

Drag M (2010) Emerging principles in protease-based drug discovery. Nat Rev Drug Discov 9:690-701

Heinis C, Rutherford T, Freund S, Winter G (2009) Phage-encoded combinatorial chemical libraries based on bicyclic peptides. Nat Chem Biol 5:502-507

Lindhout T, Willems G, Blezer R, Hemker HC (1994) Kinetics of the inhibition of human factor Xa by full-length and truncated recombinant tissue factor pathway inhibitor. Biochem J 297:131-136

Masuda-Momma K, Hatanaka T, Inouye K, Kanaori K, Tamura A, Akasaka K, Kojima S, Kumagai I, Miura K, Tonomura B (1993) Interaction of subtilisin BPN' and recombinant Streptomyces subtilisin inhibitors with substituted P1 site residues. J Biochem 114:553-559
Pan AC, Borhani DW, Dror RO, Shaw DE (2013) Molecular determinants of drug-receptor binding kinetics. Drug Discov Today 18:667-673

Rhodes CA, Dehua P (2017) Bicyclic peptides as next-generation therapeutics. Chemistry 23:12690-12703

Sagawa T, Oda M, Ishimura M, Furukawa K, Azuma T (2003) Thermodynamic and kinetic aspects of antibody evolution during the immune response to hapten. Mol Immunol 39:801-808

Shimizu Y, Ogawa K, Nakayama M (2016) Characterization of kinetic binding properties of unlabeled ligands via a preincubation endpoint binding approach. J Biomol Screen 21:729-737

Steukers M, Schaus JM, van Gool R, Hoyoux A, Richalet P, Sexton DJ, Nixon AE, Vanhove M (2006) Rapid kinetic-based screening of human Fab fragments. J Immunol Methods 310:126-135

Teufel DP, Bennett G, Harrison H, van Rietschoten K, Pavan S, Stace C, Le Floch F, Van Bergen T, Vermassen E, Barbeaux P, Hu TT, Feyen JHM, Vanhove M (2018) Stable and long-lasting, novel bicyclic peptide plasma kallikrein inhibitors for the treatment of diabetic macular edema. J Med Chem 61:2823-2836

Tonge PJ (2018) Drug-target kinetics in drug discovery. ACS Chem Neurosci 9:29-39

Ulmer JS, Lindquist RN, Dennis MS, Lazarus RA (1995) Ecotin is a potent inhibitor of the contact system proteases factor XIIa and plasma kallikrein. FEBS Lett 365:159-163

Vanhove E, Vanhove M (2018) Affinity determination of biomolecules: a kinetic model for the analysis of pre-equilibrium titration curves. Eur Biophys J 47:961-966

Wilkes SH, Prescott JM (1985) The slow, tight binding of bestatin and amastatin to aminopeptidases. J Biol Chem 260:13154-13162

Yiallouros I, Vassiliou S, Yiotakis A, Zwilling R, Stöcker W, Dive V (1998) Phosphinic peptides, the first potent inhibitors of astacin, behave as extremely slow-binding inhibitors. Biochem J 331:375-379

Zeilinger M, Pichler F, Nics L, Wadsak W, Spreitzer H, Hacker M, Mitterhauser M (2017) New approaches for the reliable in vitro assessment of binding affinity based on high-resolution real-time data acquisition of radioligand-receptor binding kinetics. EJNMMI Res 7:22. https://doi.org/10.1186/s13550-016-0249-9

Publisher's Note Springer Nature remains neutral with regard to jurisdictional claims in published maps and institutional affiliations. 